\title{
Original article (Orijinal araştırma) \\ New records for the horse fly (Diptera: Tabanidae) fauna of Turkey and description of Hybomitra tanatmisi sp. nov. ${ }^{1}$
}

\author{
Türkiye at sineği (Diptera: Tabanidae) faunası için yeni kayıtlar ve \\ Hybomitra tanatmisi sp. nov.'nin deskripsiyonu
}

Ferhat ALTUNSOY ${ }^{*}$

\begin{abstract}
Due to the geographical location of Turkey and its special geological, geomorphological and climatic features, Turkish Tabanidae fauna (Insecta: Diptera) have great species richness with 171 known species and 15 subspecies. The main purpose of the study was to contribute to the Tabanidae fauna of Turkey. Specimens were collected from Black Sea Region of Turkey between 2009 and 2015 with Malaise and Nzi traps which were baited with 1-octen-3-ol. As a result of the study, new records for Turkey, Hybomitra arpadi (Szilady, 1923), Hybomitra aterrima (Meigen, 1820), Hybomitra montana (Meigen, 1820) and Hybomitra morgani (Surcouf, 1912), are presented and Hybomitra tanatmisi sp. nov. is described. Distribution, adult and larval habitats and zoogeography of these species are briefly discussed.
\end{abstract}

Keywords: Anatolia, fauna, horse fly, Hybomitra, Tabanidae, Turkey

\section{Öz}

Türkiye'nin coğrafik lokasyonu ve jeolojik, jeomorfolojik ve klimatik özellikleri sayesinde, Türkiye Tabanidae faunası (Insecta: Diptera) 171 tür ve 15 alt tür ile büyük tür çeşitliliğine sahiptir. Çalışmanın temel amacı, Türkiye'nin Tabanidae faunasına katkıda bulunmaktır. Örnekler 2009 ve 2015 yılları arasında Türkiye'nin Karadeniz Bölgesi'nden, 1-octen-3-ol'e batırılmış Malezya ve Nzi tuzakları kullanılarak toplanmıştır. Çalışmanın sonucu olarak, Türkiye faunası için yeni kayıt olan Hybomitra arpadi (Szilady, 1923), Hybomitra aterrima (Meigen, 1820), Hybomitra montana (Meigen, 1820) ve Hybomitra morgani (Surcouf, 1912) türleri sunulmuştur ve Hybomitra tanatmisi sp. nov.'nin tanımlaması yapılmıştır. Bu türlerin dağılımları, ergin ve larva habitatları ile zoocoğrafik özellikleri kısaca tartışılmıştır.

Anahtar sözcükler: Anadolu, fauna, at sineği, Hybomitra, Tabanidae, Türkiye

\footnotetext{
${ }^{1}$ This work was supported by the Research Foundation of Anadolu University (Project Number: 1502F074) and presented as poster at the 3rd International Congress on Zoology and Technology (12-15 July 2017, Afyon, Turkey).

${ }^{2}$ Anadolu University, Faculty of Science, Department of Biology, Entomology Section, 26470, Eskişehir, Turkey

* Corresponding author (Sorumlu yazar) e-mail: tabanidae@msn.com

Received (Alınış): 05.03.2018 Accepted (Kabul ediliş): 27.04.2018Ｐublished Online (Çevrimiçi Yayın Tarihi): 19.05 .2018
} 


\section{Introduction}

Female horse flies cause considerable problems both medically and economically during their blood-feeding period. Their importance is associated with both transmission of diseases, their economic impact when they occur in large numbers and their persistent and painful bites which irritate grazing animals considerably with resulting weight loss, decreased milk production and allergic responses. (Chvala et al., 1972; Olsufjev, 1977; Foil, 1989).

Due to its geographical location, the territory of Turkey has special geological, geomorphological and climatic features that make it one of the most important places in the Palearctic Region for studying the horse fly fauna. Asia Minor, one of the most remote areas of the Eastern Mediterranean, has a large number of faunistic elements that congregate from the three main parts of the Palearctic region, Mediterranean, Asian and European. Almost all of these species can find suitable habitats in the main part of Asia Minor because of the high diversity of various landscapes, climatic conditions, mountain chains with vertical zonation, plains along the rivers and seashores, all of which are found in Turkey. Based on previous studies, Turkish Tabanidae fauna (Insecta: Diptera) includes 171 species and 15 subspecies (Kılıç, 2006; Andreeva et al., 2009; Altunsoy \& Kılıç, 2010, 2014) that represents almost $30 \%$ of Palearctic fauna of 610 species (Chvala, 1988; Andreeva, 2004). Earlier studies on the horse fly fauna of Turkey were made by international researchers between 1850 and 1960 (Walker, 1854; Loew, 1856; Austen, 1925; Leclercq, 1966a, b, 1967a, b). More recent studies have been more comprehensive being mostly conducted by local researchers, and include many new records and new species in the horse fly fauna of Turkey (Schacht, 1983, 1984, 1985, 1987; Yücel, 1987; Erdoğmuş, 1992; Hayat \& Özbek, 1992; Kılıç, 1992, 1995, 1996a, b, c, 1997, 1999, 2001a, b, c, 2003, 2004, 2005; Kılıç \& Schacht, 1995; Kılıç \& Öztürk, 2002; Altunsoy et al., 2010; Altunsoy \& Kılıç, 2010, 2011; Büber et al., 2011). In this study, four species were added to the horsefly fauna of Turkey and one new species is described.

\section{Material and Methods}

\section{Sampling and collecting method}

Adult specimens of the horse fly were collected with Malaise and Nzi traps, baited with 1-octen-3$\mathrm{ol}$, and water traps. The water trap used for male tabanids was based on Barnes (2018). Octenol is well known as an attractant for horse flies as reported by Altunsoy \& Afacan (2014), Mihok et al. (2007) and Krčmar et al. (2005, 2006, 2009). Trapping was done during daylight from 8 am to 7 pm. Collection and preparation of specimens were done according to the methods of Chvala et al. (1972) and Olsufjev (1977).

\section{Identification and morphological study}

Specimens were identified according to Chvala et al. (1972), Olsufjev (1977), Peus (1980), Schacht (1987), Leclercq (1966a, b; 1967a, b) and Rubio (2002). The identification of the specimens was made using Leica MZ7,5 stereo microscope.

The taxonomic status of the species was checked according to the recent updates of Fauna Europaea, Global Species and Chvala (1988).

The Atlas of Insect Morphology (Steinmann \& Zombory, 1985) was used for description of adult tabanids and specific terminology for Tabanidae was used according to Chvala et al. (1972). Identified specimens are preserved in the Zoological Museum of Anadolu University (AUZM).

\section{Study area}

Study was conducted in Ardahan, Artvin, Bartın and Bolu Provinces in the central and northeastern parts of Black Sea Region of Turkey between 2009 and 2015. Localities, coordinates, altitude, habitats and dates are presented in Table 1. Distribution of each species is summarized according to Chvala et al. (1972), Chvala (1988) and the Catalogue of Life: Systema Dipterorum (Anonymous, 2018). 
Table 1. Study areas and habitats

\begin{tabular}{|c|c|c|c|c|c|}
\hline \multicolumn{2}{|c|}{ Locality } & \multirow{2}{*}{ Coordinates } & \multirow{2}{*}{ Altitude $(\mathrm{m})$} & \multirow{2}{*}{ Habitat } & \multirow{2}{*}{ Date } \\
\hline Province & District & & & & \\
\hline Ardahan & Pasof & $41^{\circ} 29^{\prime} 52^{\prime \prime} \mathrm{N}, 42^{\circ} 44^{\prime} 24^{\prime \prime} \mathrm{E}$ & 1360 & Abies-Picea forest & 30 July 2011 \\
\hline \multirow{4}{*}{ Artvin } & Maçahel & $41^{\circ} 29^{\prime} 36^{\prime \prime} \mathrm{N}, 41^{\circ} 56^{\prime} 57^{\prime \prime} \mathrm{E}$ & 976 & Abies-Picea-Pinus forest & 28 July 2011 \\
\hline & Maçahel & $41^{\circ} 29^{\prime} 36^{\prime \prime} \mathrm{N}, 41^{\circ} 59^{\prime} 57^{\prime \prime} \mathrm{E}$ & 1276 & Abies-Picea forest & 28 July 2011 \\
\hline & Borçka & $41^{\circ} 23^{\prime} 32^{\prime \prime} \mathrm{N}, 41^{\circ} 51^{\prime} 13^{\prime \prime} \mathrm{E}$ & 1470 & Abies-Picea forest & 25 June 2010 \\
\hline & Borçka & $41^{\circ} 23^{\prime} 32^{\prime \prime} \mathrm{N}, 41^{\circ} 51^{\prime} 13^{\prime \prime} \mathrm{E}$ & 1470 & Abies-Picea forest & 15 June 2012 \\
\hline Bolu & Gölcük & $40^{\circ} 32^{\prime} 38^{\prime \prime} \mathrm{N}, 31^{\circ} 36^{\prime \prime} 10^{\prime \prime} \mathrm{E}$ & 1380 & Pinus forest & 18 June 2009 \\
\hline \multirow{2}{*}{ Bartın } & Kurucaşile & $41^{\circ} 47^{\prime} 51^{\prime \prime} \mathrm{N}, 32^{\circ} 34^{\prime} 43^{\prime \prime} \mathrm{E}$ & 320 & Quercus forest & 20 June 2015 \\
\hline & Kurucaşile & $41^{\circ} 48^{\prime} 21^{\prime \prime} \mathrm{N}, 32^{\circ} 35^{\prime} 24^{\prime \prime} \mathrm{E}$ & 250 & Quercus forest & 22 June 2011 \\
\hline
\end{tabular}

\section{Results and Discussion}

In total, 24 specimens belonging to the Tabaninae subfamily, were examined and four species are determined as new records for Turkey: Hybomitra arpadi (Szilady, 1923), $H$. aterrima (Meigen 1820), $H$. montana (Meigen, 1820) and $H$. morgani (Surcouf, 1912). Hybomitra tanatmisi sp. nov. is described.

Order: Diptera

Family: Tabanidae

Subfamily: Tabaninae

Tribe: Tabanini

Genus: Hybomitra Enderlein, 1922

Hybomitra arpadi (Szilady, 1923) (Figure 1)

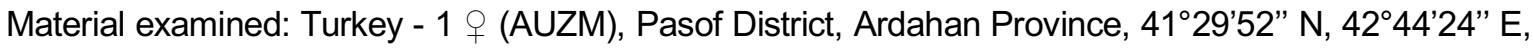

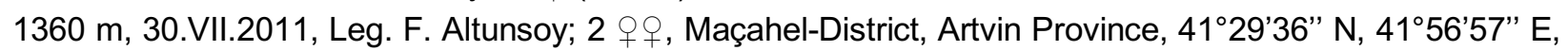
976 m, 28.VII.2011, Leg. F. Altunsoy.

Type locality: Alaska; chorotype: A Holarctic species that commonly known from Scandinavia especially Sweden and Finland, it has a wide area of distribution from northern parts of America, occurs in regions of Moscow, Kamtchatka and Southwest Germany, and rarely in Japan. This is the first record for the Turkey. Three female specimens were collected in the early to late afternoon in July 2011.

Comments: This species occurring mostly in taiga and forests in the north in Central Europe on peat-bogs and hilly countries. Specimens (adult and larvae) were collected from marshy habitats in pine forests. Hybomitra arpadi is not a highly variable species but as reported by Dvorák and Petrašiunas (2010) identification of this species is difficult and requires more experience and accurate identified material for comparison. Some members of the $H$. bimaculata $[H$. bimaculata (Macquart, 1826), $H$. distinguenda (Verrall, 1909), H. muehlfeldi (Brauer, 1880)] and H. montana (especially H. lundbecki Lyneborg, 1959) groups are quite similar to $H$. arpadi (Szilady, 1923). 


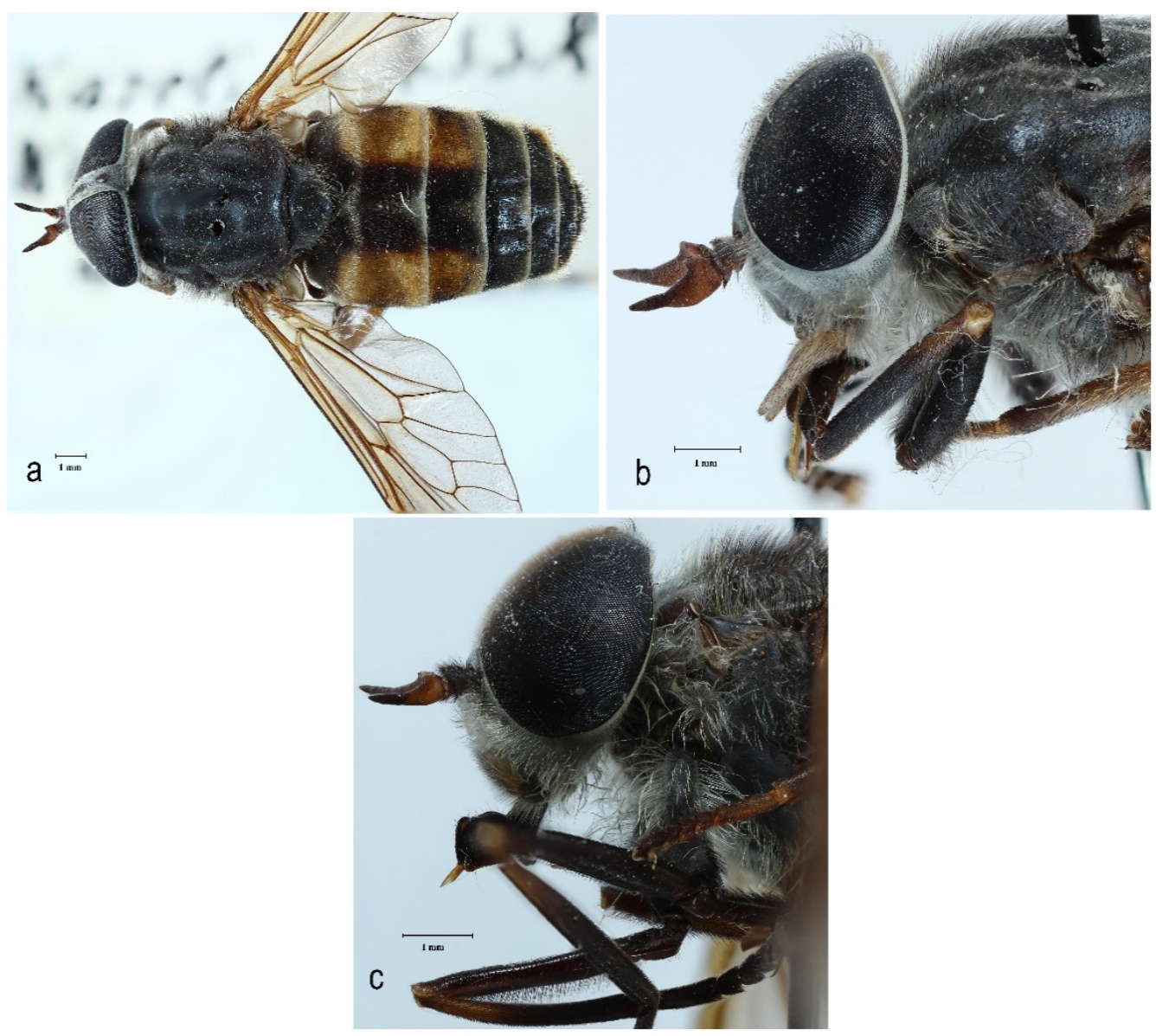

Figure 1. Hybomitra arpadi : a) dorsal view; b) antenna and palp $\odot$; and c) antenna and palp $\hat{\jmath}$.

Hybomitra aterrima (Meigen, 1820) (Figure 2)

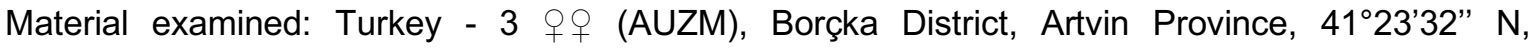

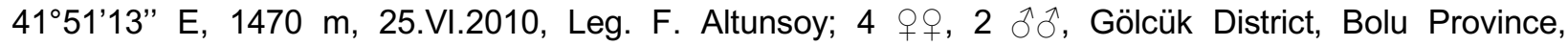
40³2'38" N, 3136"10" E, 1380 m, 18.VI.2009, Leg. A. Y. Kılıç; 2 우우, Maçahel District, Artvin Province,

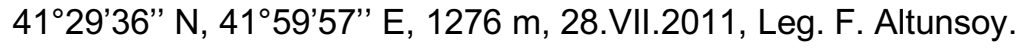

Type locality: Sweden, chorotype: A boreo-mountainous species known from North Europe from Scandinavia (Norway, Sweden and Finland) and can also be observed in mountains of Central and South Europe. It is known from the Alps up to $2400 \mathrm{~m}$ from France, South Germany and Central Austria. This is the first record for Turkey. In total, 11 specimens were collected in the afternoon from three different locations in three different years.

Comments: $H$. aterrima easily distinguishable from other closely related species with abdominal pubescence and entirely black abdomen, legs, antennae, face and slender palpi black haired. Larvae were collected from moist habitats between pine and oak forests. Adults are found near edaphobiotic habitats. 


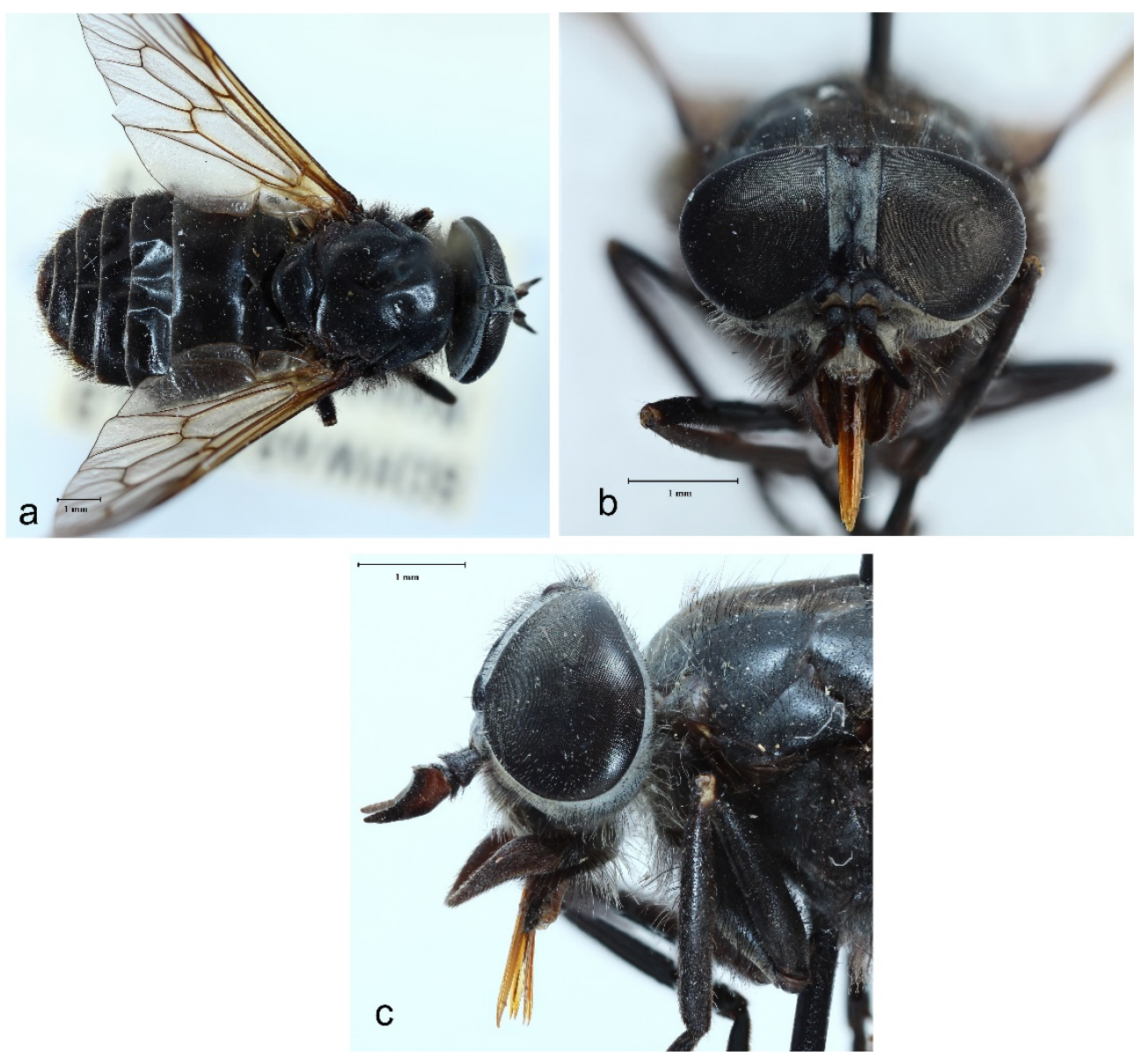

Figure 2. Hybomitra aterrima $q$ : a) dorsal view; b) frons; and c) antenna and palp.

Hybomitra montana (Meigen, 1820) (Figure 3)

Material examined: Turkey - 4 우 (AUZM), Pasof District, Ardahan Province, 41 ${ }^{\circ} 29^{\prime} 52^{\prime \prime} \mathrm{N}$, 424'24" E, 1360 m, 28.VII.2011, Leg. A. Y. Kılıç; 6 우우, Karagöl, Borçka District, Artvin Province, $41^{\circ} 23^{\prime} 32^{\prime \prime} \mathrm{N}, 41^{\circ} 51^{\prime} 13^{\prime \prime}$ E, 1470 m, 15.VI.2012, Leg. F. Altunsoy.

Type locality: Germany, chorotype: It is a widely distributed species in the Palearctic region especially in British Isles including Ireland and Scandinavia. It has also been recorded from West Austria, North Italy, Germany, Netherlands, Spain, France, Slovenia, China, Korea and Japan. This is the first record for Turkey. In total, 10 female specimens were collected in two different locations in 2011 and 2012.

Comments: This species is mainly found in hilly to mountainous areas; but is not restricted to such places. Larvae were collected from moist habitats between pine and oak forests. Adults were found near edaphobiotic habitats. Hybomitra montana (Meigen, 1820) is an extensively darkened species and some variability can be seen in brownish side markings on the first tergites. However, the antennae are more slender and darker than the nominate form. 

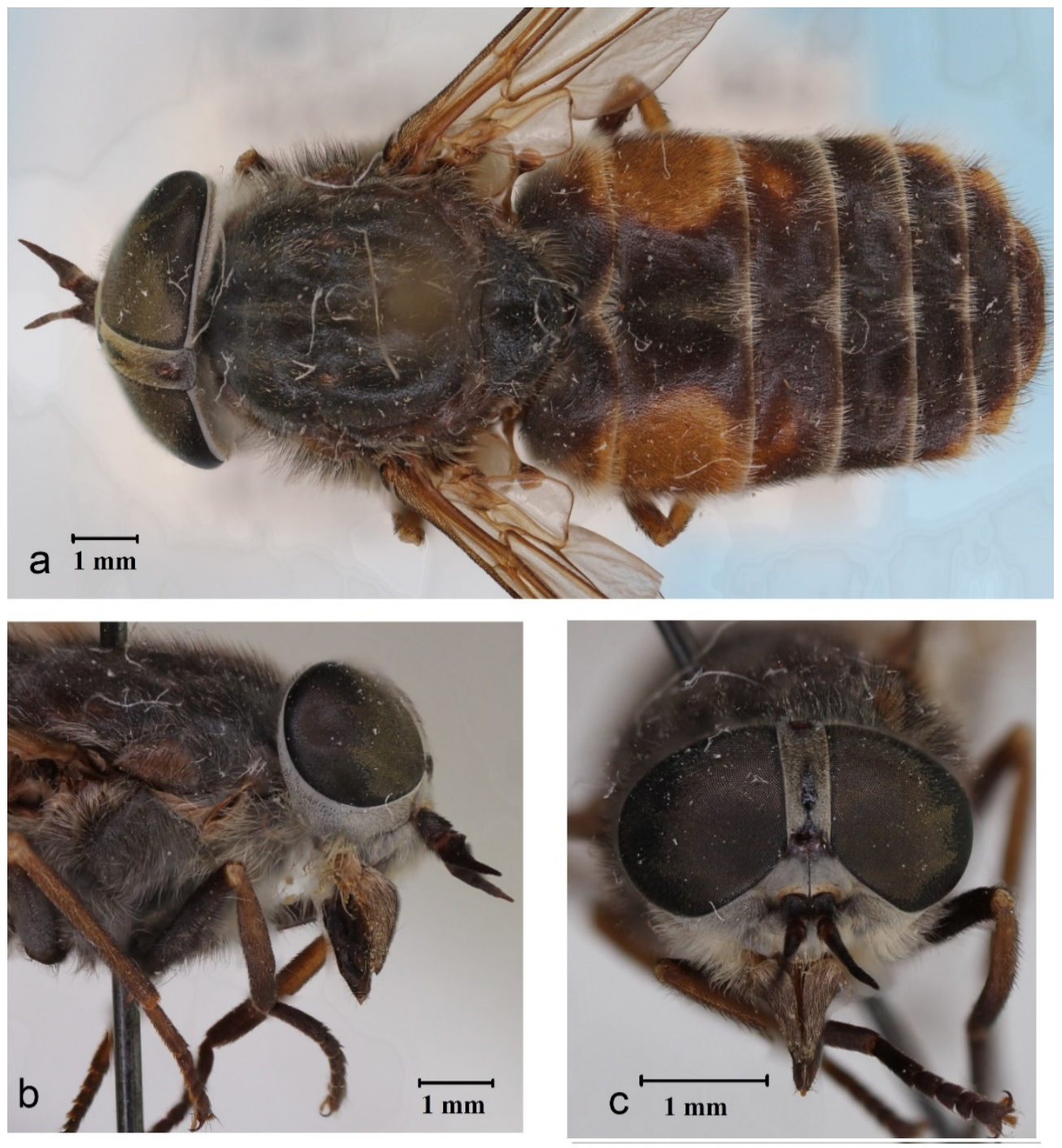

Figure 3. Hybomitra montana $\rho_{\text {: }}$ a) dorsal view; b) antenna and palp; and c) frons.

Hybomitra morgani (Surcouf, 1912) (Figure 4)

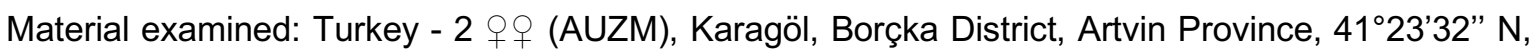

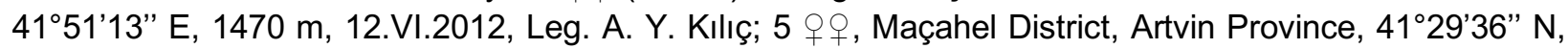
$41^{\circ} 56$ '57' E, 976 m, 18.VI.2012, Leg. F. Altunsoy.

Type locality: Iran, chorotype: The area of distribution of this species is not well known but confirmed from Denmark, Russia, Middle Asia, Iran, Georgia, Armenia, Mongolia, Azerbaijan and China. This is the first record for Turkey. In total, seven female specimens were collected during late afternoon from two different locations in June of 2011 and 2012.

Comments: This species inhabits various types of biotopes, but it occurs most frequently in forest regions, especially pine forests. Larvae and pupae were collected from moist habitats between pine and oak forests. Adults were found near edaphobiotic habitats. 

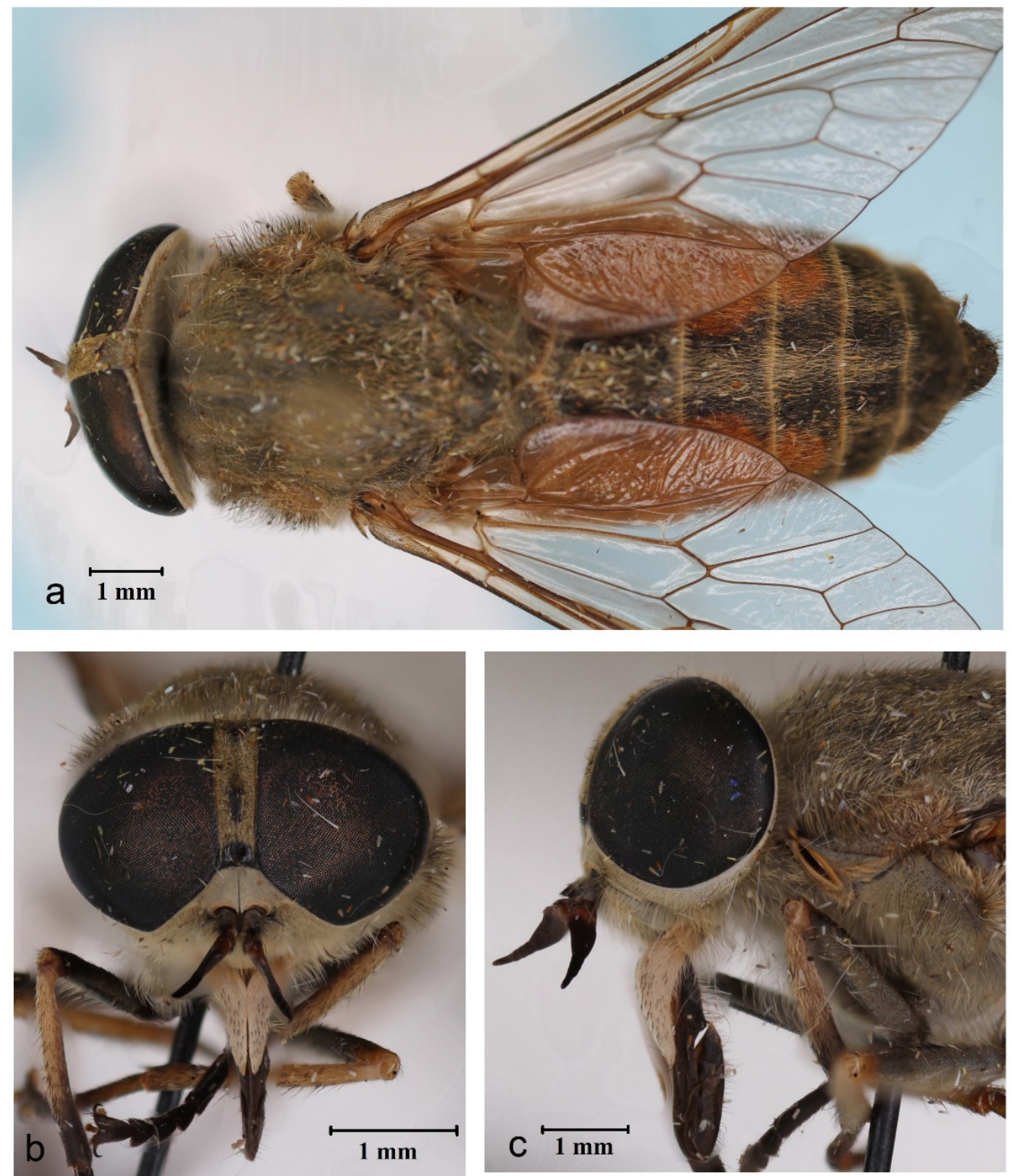

Figure 4. Hybomitra morgani + : a) Dorsal view; b) frons; and c) Antenna and palp.

Hybomitra tanatmisi sp. nov. (Figures 5 \& 8)

Material examined: Holotype: 1 q Turkey (AUZM), Kanatlı Village, Kurucaşile District, Bartın

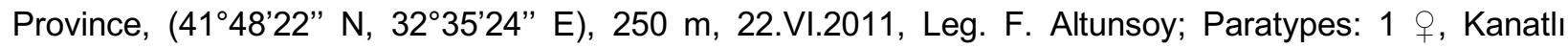

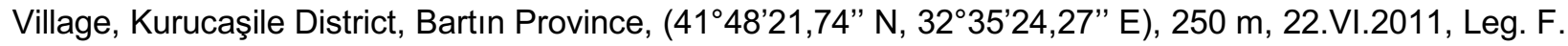

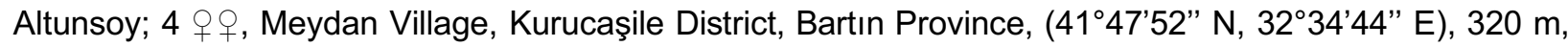
20.VI.2015, Leg. F. Altunsoy.

Etymology: The new species is dedicated to Mustafa Tanatmış, a Turkish entomologist who is respected colleague of the authors. We are thankful to his important research and valuable contributions to entomology. 
Diagnosis: The new species has characteristic features of the $H$. bimaculata group, which are frontal index 1:4-6, distinctly wrinkled above, lower callus small and distinctly wrinkled, not polished (Figures 5 \& 8). Smaller to medium sized length, 13-16 mm, brownish species with chestnut brown side markings on the anterior three tergites. Notopleural lobes are black and long yellowish haired. Frons narrow, lower callus small and distinctly wrinkled, antennae reddish-brown, basal segment long black haired. Closely related with $H$. muehlfeldi, $H$. distinguenda, H. bimaculata and $H$. ciureai (Seguy, 1937). Distinctive characters of this species with closely related species are given in Table 2.
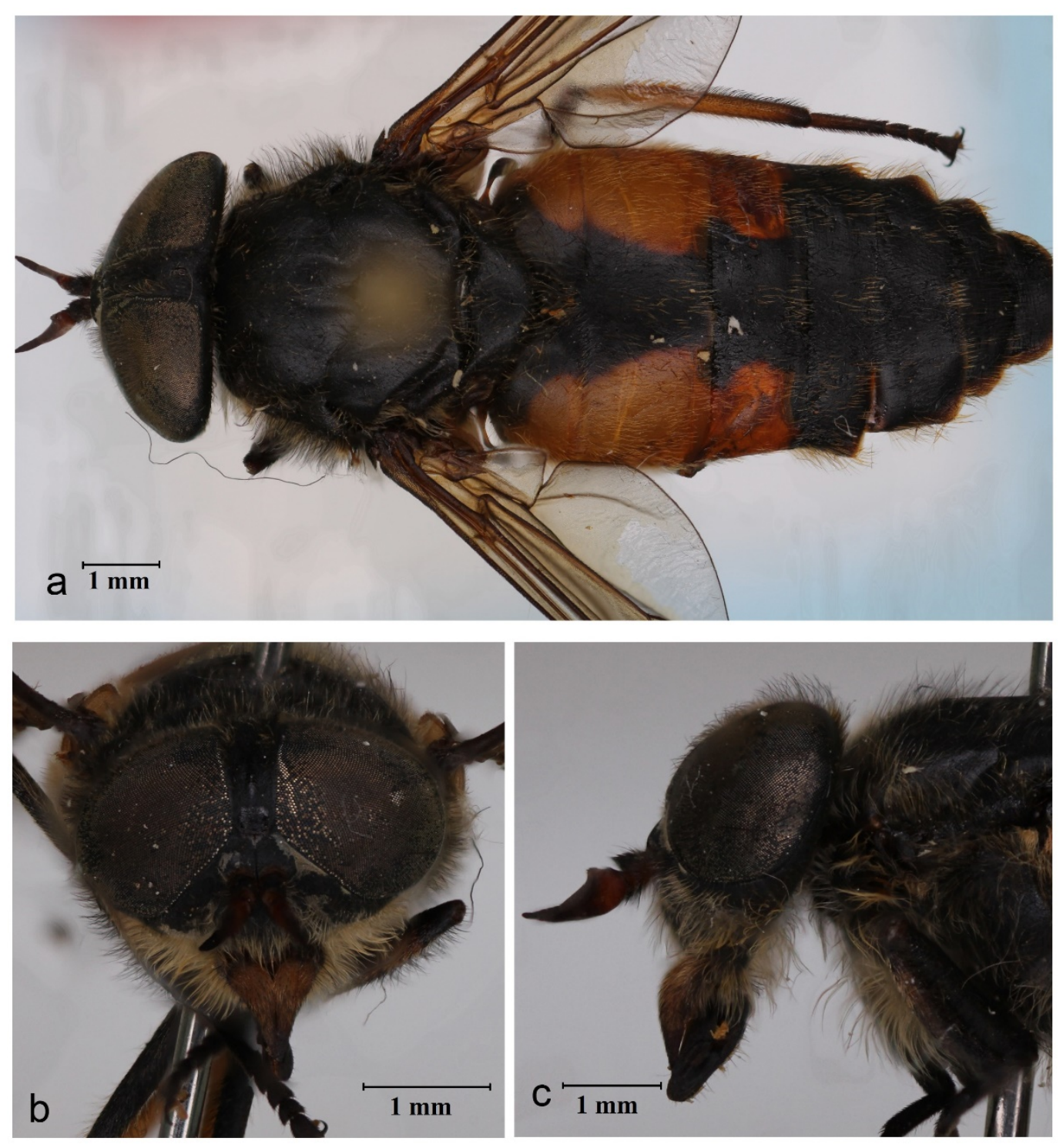

Figure 5. Hybomitra tanatmisi sp. nov. $q$ : a) dorsal view; b) frons; and c) antenna and palp. 
Table 2. Distinctive characters of Hybomitra tanatmisi sp. nov. compared to four closely related Hybomitra spp.

\begin{tabular}{|c|c|c|c|c|c|}
\hline Features & H. tanatmisi & H. ciureai & H. muehlfeldi & H. distinguenda & H. bimaculata \\
\hline Frons index & $1: 5-5.5$ & $1: 4-4.5$ & $1: 5-6$ & $1: 5-6$ & $1: 4.5-5$ \\
\hline Antenna & reddish-brown & reddish-brown & reddish-brown & brown to reddish-brown & $\begin{array}{l}\text { Reddish-brown to } \\
\text { blackish-brown }\end{array}$ \\
\hline $\begin{array}{l}\text { Basal antennal } \\
\text { segment }\end{array}$ & $\begin{array}{l}\text { reddish-brown and } \\
\text { gray dusted }\end{array}$ & $\begin{array}{l}\text { reddish-brown } \\
\text { and black haired }\end{array}$ & $\begin{array}{l}\text { brown, densely } \\
\text { grayish dusted and } \\
\text { short black haired }\end{array}$ & $\begin{array}{l}\text { densely grayish-black } \\
\text { dusted and mostly pale } \\
\text { haired }\end{array}$ & $\begin{array}{l}\text { blackish-gray covered } \\
\text { and gray dusted and } \\
\text { densely black } \\
\text { pubescent }\end{array}$ \\
\hline Palpus & $\begin{array}{l}\text { yellowish-brown, } \\
\text { long yellow short } \\
\text { black haired }\end{array}$ & $\begin{array}{l}\text { light brown to } \\
\text { yellowish-gray, } \\
\text { mostly pale } \\
\text { haired and some } \\
\text { black haired }\end{array}$ & $\begin{array}{l}\text { yellowish-brown to } \\
\text { grayish-brown, } \\
\text { apical segment } \\
\text { clothed with pale } \\
\text { and black hairs }\end{array}$ & $\begin{array}{l}\text { grayish brown to brown } \\
\text { apical segment stout at } \\
\text { base, covered with } \\
\text { short black hairs and } \\
\text { longer pale ones }\end{array}$ & $\begin{array}{l}\text { grayish-yellow, apical } \\
\text { segment stout at base, } \\
\text { clothed with mostly } \\
\text { short black hairs }\end{array}$ \\
\hline $\begin{array}{l}\text { Notoplaural } \\
\text { lobes }\end{array}$ & $\begin{array}{l}\text { black and short } \\
\text { black haired }\end{array}$ & yellowish-brown & partly brown & brown to blackish & blackish-gray \\
\hline Wings & $\begin{array}{l}\text { saliently brownish } \\
\text { colored along } \\
\text { costal margin }\end{array}$ & $\begin{array}{l}\text { slightly tinted } \\
\text { yellowish along } \\
\text { costal margin }\end{array}$ & $\begin{array}{l}\text { slightly brownish } \\
\text { clouded along } \\
\text { costal margin and } \\
\text { in basal cell }\end{array}$ & $\begin{array}{l}\text { distinctly brownish } \\
\text { clouded along costal } \\
\text { margin }\end{array}$ & $\begin{array}{l}\text { clear costal margin and } \\
\text { especially costal cell } \\
\text { slightly brownish }\end{array}$ \\
\hline Cerci & $\begin{array}{l}\text { Slender eliptic } \\
\text { shape (Figure 6a) }\end{array}$ & $\begin{array}{l}\text { rectangular with } \\
\text { oblique lateral } \\
\text { edges (Figure 6b) }\end{array}$ & $\begin{array}{l}\text { conspicuously high } \\
\text { and narrow, } \\
\text { apically rounded } \\
\text { (Figure 6c) }\end{array}$ & $\begin{array}{l}\text { broadly rectangular } \\
\text { with rounded lateral } \\
\text { edges (Figure } 6 \mathrm{~d} \text { ) }\end{array}$ & $\begin{array}{l}\text { conspicuously slender, } \\
\text { rectangular (Figure 6e) }\end{array}$ \\
\hline $\begin{array}{l}\text { Subgenital } \\
\text { plate }\end{array}$ & $\begin{array}{l}\text { Equal length } \\
\text { (Figure } 7 a \text { ) }\end{array}$ & $\begin{array}{l}\text { with a deep } \\
\text { excision on lower } \\
\text { margin, upper } \\
\text { part regularly } \\
\text { semiglobular } \\
\text { (Figure } 7 \mathrm{~b} \text { ) }\end{array}$ & $\begin{array}{l}\text { higher than broad } \\
\text { (Figure 7c) }\end{array}$ & $\begin{array}{l}\text { straight on lower } \\
\text { margin upper part } \\
\text { rather broad with only a } \\
\text { slight excision above } \\
\text { (Figure } 7 d \text { ) }\end{array}$ & $\begin{array}{l}\text { broad, upper margin } \\
\text { broadly semiglobular } \\
\text { with a small indication } \\
\text { of median excision, } \\
\text { lower margin straight } \\
\text { (Figure } 7 e \text { ) }\end{array}$ \\
\hline
\end{tabular}

Description: 9

Head: Eyes; long yellowish-brown haired with three purple bands. Frons; yellowish-brown dusted, long yellowish and black haired, narrow index 1:5-5.5, widened towards vertex, Lower callus large, blackish-brown, square and connected with median callus. Ocellar tubercule shining dark brown and triangular. Subcallus gray dusted and naked. Face and cheek grayish dusted and long yellowish haired. Vertex short yellow haired. Scape and pedicel segments reddish-brown in ground color. Scape gray dusted and long black haired. Pedicel black and reddish-brown haired. Third segment reddish-brown dorsal tooth not well developed and short minute black haired. Flagellar segments blackish-brown. Apical segment of palpi long and slender, about three, five times as long as deep, yellowish-brown, long yellow and short black haired. First segment of palpi blackish and long yellow haired.

Thorax: Black, mesonotum and scutellum blackish grey dusted with yellowish-grey haired. Pleura black ground color, gray pubescent long yellowish haired. Mesonotum with indefinite grayish longitudinal stripes, short black and yellowish haired. Notopleural lobes black and short black haired. Legs; femur grayish-black and long yellow haired. Femur black, short yellowish haired. Tibia light brown, at posterior black and at anterior yellowish haired. Tarsus dark brown and black haired. Wings; veins, blackish-brown to black, saliently brownish clouded along the costal margin and basal cells. Halters dark brown and knop slightly grayish at the tip. 


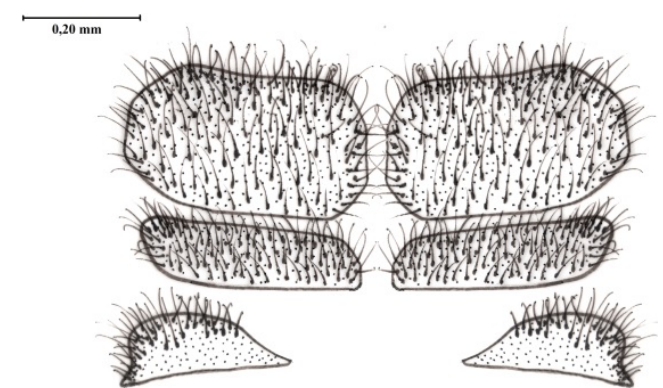

a

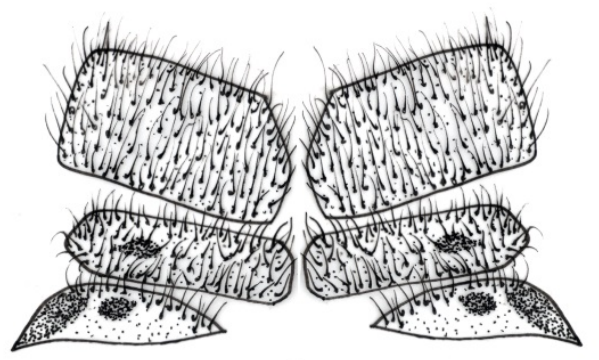

C

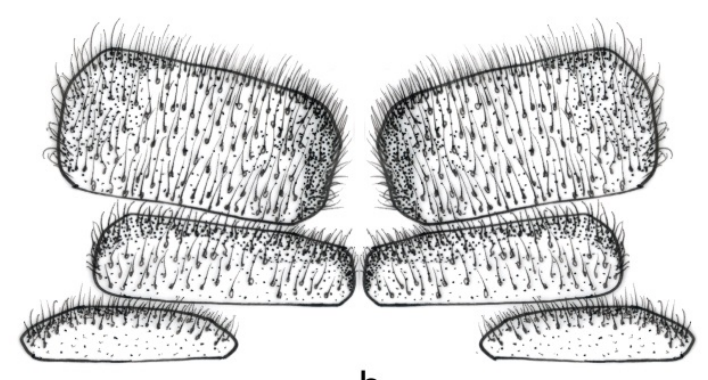

b

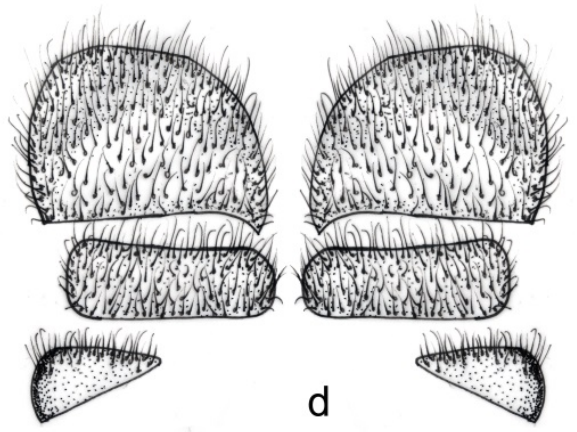

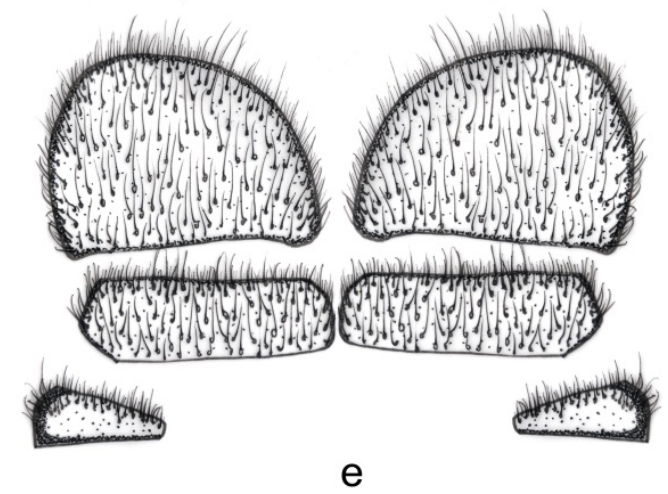

e

Figure 6. Cerci of species: a) Hybomitra tanatmisi sp. nov.; b) Hybomitra ciureai; c) Hybomitra muehlfeldi; d) Hybomitra distinguenda; and e) Hybomitra bimaculata.

Abdomen: Black anterior three tergites chestnut brown at sides. Brown side marking distinctly yellow haired. Black median stripes broader, occupying at least third of the tergite on segment 2, slightly with a row of none or least distinct colored and silvery pubescent median triangles. Vertex black, anterior four sternite chestnut brown. Subgenital plate, U-shaped 0,86 $\mathrm{mm}$ long and 0,86 mm broad. Apical part of subgenital yellowish-brown. Subgenital densely long and pale brown haired. Subgenital plate with excision on lower margin and upper part semi globular (Figure 7a). Cerci 0,54 mm long and 0,84 mm broad, yellowish-brown colored and slightly black haired. Cerci rectangular with oblique sides (Figure 6a). Spermatheca (Figure 9) W-shaped and oblique at tip, three of ejection apparatus are $0.23 \mathrm{~mm}$ and with valve shaped in the distal end. Three of them same length and shape. Reservoir elliptic shape and dark brown color with $4 / 3$ part of distal tubes. 


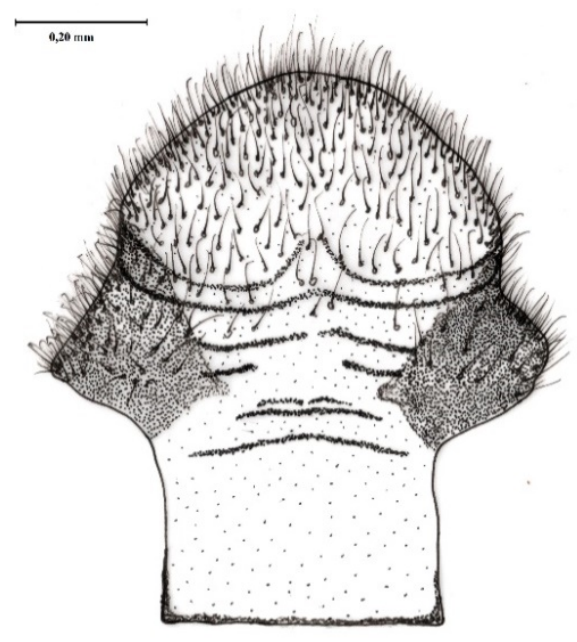

a

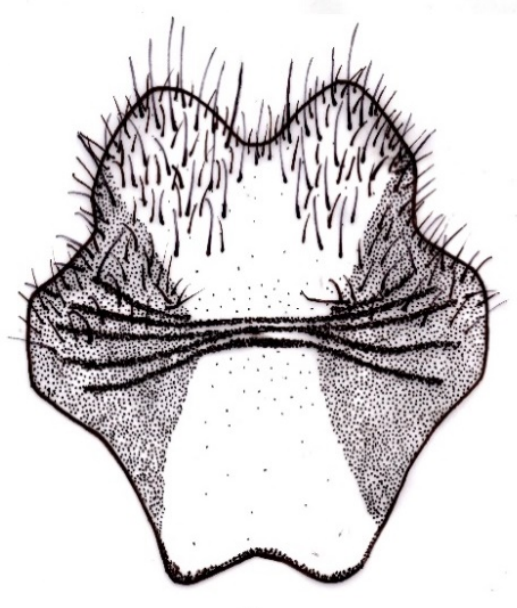

C

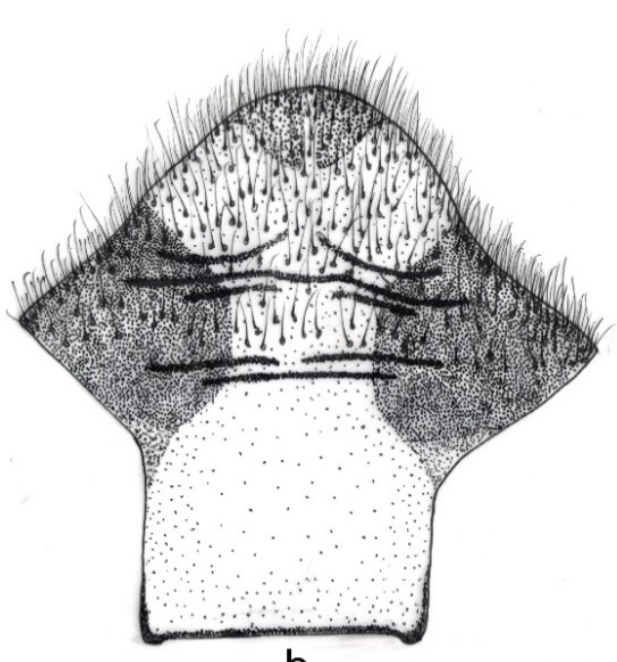

b

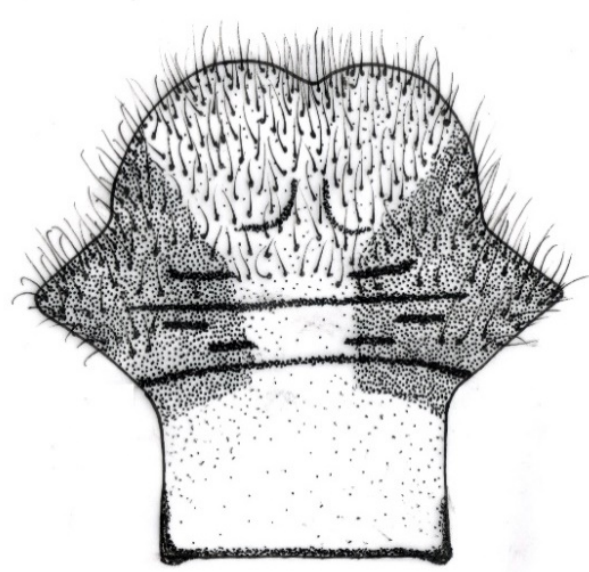

d

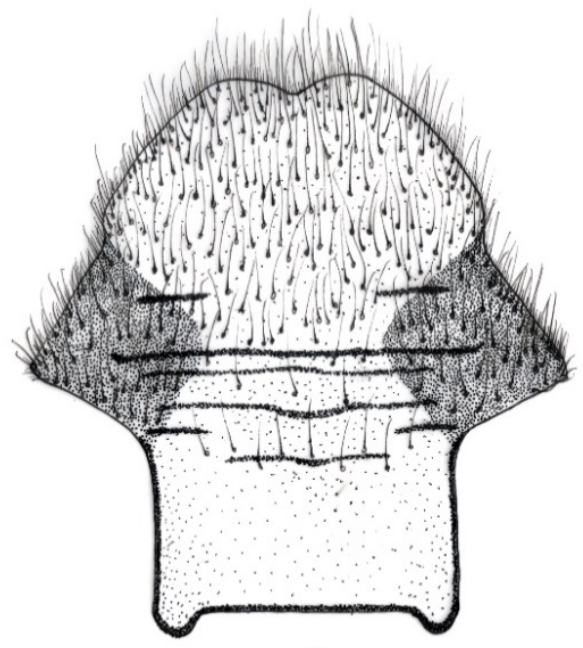

e

Figure 7. Subgenital plates of species: a) Hybomitra tanatmisi sp. nov.; b) Hybomitra ciureai; c) Hybomitra muehlfeldi; d) Hybomitra distinguenda; and e) Hybomitra bimaculata. 
Variability: This species is not highly variable, but side markings on the abdomen of same samples extensively darkened and blackish-red colored. In contract, the third segment of antennae blackish-brown colored and light gray dusted and dorsal tooth little developed and minute black and dark gray haired. Subgenital plate and cerci are not variable, but coloration and shape of the reservoir of spermatheca is quite variable.

Comments: Generally, species of Hybomitra are found between 1100-1900 m altitude near pine and oak forests, but this species was found at 200-500 m altitude in moist pine forests. Probably this species is endemic to Turkey especially for the Middle Black Sea Region. Adults are edaphobiotic, and probably females lay eggs in semi-hydrobiotic habitats in these pine forests. Seasonal activity of the species is extremely short compared to other species of Hybomitra, and was from mid-June to the first week of July in 2011. Specimens were collected in the early afternoon.

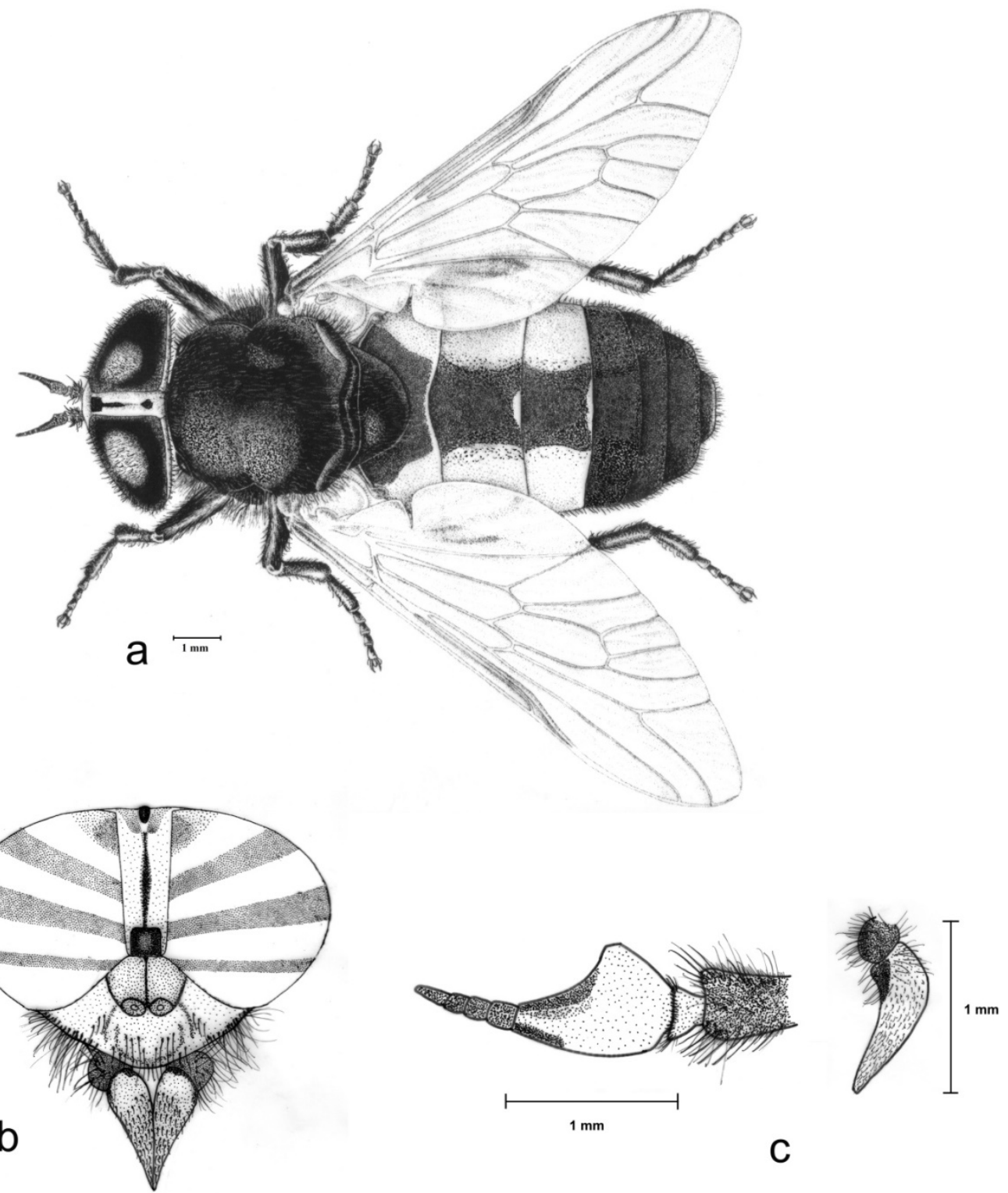

Figure 8. Hybomitra tanatmisi sp. nov. $९$ : a) dorsal view; b) frons; and c) antenna and palp. 


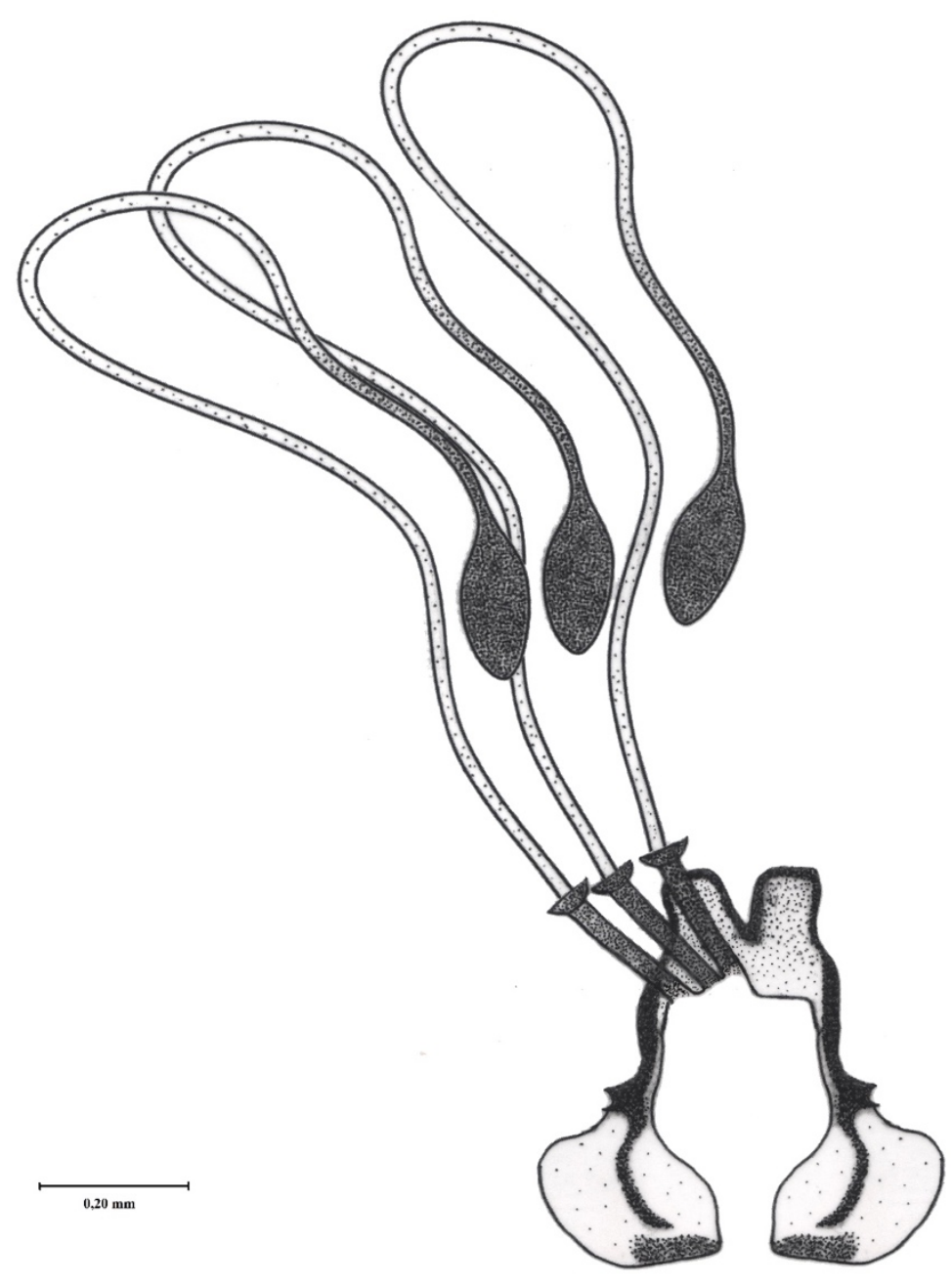

Figure 9. Spermatheca of Hybomitra tanatmisi sp. nov.

Turkey has a significant position in terms of biodiversity due to its geographic and climatic features, with three major parts of the Palearctic Region, Mediterranean, Asian and European, meeting in Turkey. Nevertheless, high mountain chains, such as Anatolian Diagonal and Black Sea Mountain lines have blocked entry to Turkey and obstructed distributions of many species. Therefore, $H$. arpadi (Szilady, 1923), $H$. montana (Meigen, 1820) and $H$. morgani (Figures $1,3 \& 4$ ) have been determined in the northern part of the Eastern Black Sea Mountains. According to the data obtained, these species cannot reach beyond the inner part of the mountain ranges of Turkey, they can only spread amongst the northern side of these mountain ranges at 3000-4000 $\mathrm{m}$ altitude. Therefore, distribution of this species is limited to the eastern side of Black Sea Region of Turkey. Whereas, H. aterrima (Figure 2) was found to the North of Middle and Eastern Black Sea Mountain chains, and $H$. tanatmisi sp. nov. was only found in moist pine forests at 200-500 m altitude in the Middle Black Sea Region. 
Especially these three species, $H$. montana, $H$. morgani, $H$. arpadi, cannot pass from the north to the south side of the Black Sea Mountains because of altitude and habitat structure where species has been found. The northern side of the Black Sea Mountains has a high precipitation rate but the southern side is colder and drier. These three species need wetland habitats to complete larval development which are always available on the north side of the Black Sea Mountains. Adults can find appropriate places to deposit eggs in forests which are full of wetland habitats, such as rivers and lakes. Whereas, the ecological and environmental conditions on the south side are generally not suitable for this species.

Descriptions of two new species, one new subspecies and eight new records for Turkey have been published (Timmer, 1984; Andreeva et al., 2009; Altunsoy \& Kılıç, 2010; Kılıç et al., 2014). Nevertheless, faunal complex and distributions of horsefly species in Turkey are not completely known. The comparative diversity of the Turkish Tabanidae to that of neighboring countries leads us to conclude that the actual diversity of this family in Turkey could be expected to be higher than that currently known. Therefore, we expect that further records for this family in Turkey will made in the future.

From this study, four species have been added to Turkish horsefly fauna, and one new species described. Therefore, the Tabanidae now consists of 176 species and 15 subspecies in Turkey. However, taking into account all previous literature, the fauna of Tabanidae of the Central Turkey region is still inadequately known.

\section{Acknowledgments}

This work was supported by the Research Foundation of Anadolu University (Project Number: 1502F074).

\section{References}

Altunsoy, F., A. Y. Kılıç \& T. Gören, 2010. Düzce Illi Tabanidae (Diptera: Insecta) faunası. Sakarya Üniversitesi Fen Bilimleri Dergisi, 14 (1): 29-32.

Altunsoy, F. \& A. Y. KIlıç, 2010. A new record for Turkish Tabanidae (Insecta: Diptera) fauna. Journal of Entomological Research Society, 12 (2): 109-111.

Altunsoy, F. \& A. Y. Kllıç, 2011. New data about Tabanus karaosus Timmer, 1984 (Diptera: Tabanidae) from Turkey. Journal of Entomological Research Society, 13 (1): 75-80.

Altunsoy, F. \& M. Y. Afacan, 2014. Response of Tabanidae (Diptera) species to malaise traps baited with 1-octan-3ol and 4-methylphenol. Journal of the Entomological Research Society, 16 (1): 111-117.

Andreeva, R. V., 2004. Additions and comments to the Catalogue of Palearctic Diptera (Tabanidae). Zeitschrift der Arbeitsgemeinschaft Osterreichischer Entomologen, 56: 93-106.

Andreeva, R., F. Altunsoy \& A.Y. Kılıç, 2009. New contribution to Information about Tabanidae (Diptera) adult and larvae from West Anatolia. Journal of the Entomological Research Society, 11 (3): 19-30.

Anonymous, 2018. Catalogue of Life: Systema Dipterorum. (Web page: http://www.catalogueoflife.org/col/details/ database/id/101) (Date accessed: 15 April 2018).

Austen, E. E., 1925. A contribution to knowledge of blood-sucking Diptera of the Dardanalles. Bulletin Entomological Research, 16: 5-22.

Barnes, A., 2018. Man built this trap in his backyard, and it's disgusting how well it works. (Web page: http://boredomtherapy.com/beat-a-dead-horsefly) (Date accessed: 15 April 2018).

Büber, H., A. Y. Kılıç \& F. Altunsoy, 2011. Afyon ili Tabanidae (Insecta: Diptera) faunasına katkılar. Afyon Kocatepe University Journal of Science, 9 (2): 43-50.

Chvala, M., 1988. “Family Tabanidae, 97-71”. In: Catalogue of Palaearctic Diptera, Vol. 5 (Eds. Á. Soós \& L. Papp). Elsevier Science Publishers, Amsterdam, The Netherlands, 446 pp.

Chvala, M., L. Lyneborg \& J. Moucha, 1972. The Horse Flies of Europe (Diptera: Tabanidae). Entomological Society, Copenhauge, E. W. Classey Ltd. Hampton, Middlesex, UK, 500 pp. 
Dvořák, L. \& A. Petrašiūnas, 2010. Hybomitra arpadi (Szilády, 1923) (Diptera: Tabanidae) has not been confirmed in Lithuania. XXVIII Nordic-Baltic Congress of Entomology (2-7 August 2010, Birštonas, Lithuania), Lithuanian Entomological Society Press, Vol:22, 130-132.

Erdoğmuş, Z., 1992. Elazığ ve Yöresinde Bulunan Tabanidae (Diptera) Türleri Üzerine Araştırmalar. Fırat Üniversitesi Sağlık Bilimleri Enstitüsü, (Yayınlanmamış) Doktora Tezi, 74 pp.

Foil, L., 1989. Tabanids as vectors of disease agents. Parasitology Today, 5: 88-96.

Hayat, R. \& H. Özbek, 1992. "Doğu Anadolu Bölgesi Tabanidae (Diptera) türleri üzerine faunistik çalışmalar, 637646”. Türkiye II. Entomoloji Kongresi Bildirileri (28-31 January 1992, Adana, Turkey) Entomoloji Derneği Yayınları, No 5, $747 \mathrm{pp}$.

Kılıç, A. Y., 1992. Eskişehir ve çevresi Tabanidae (Diptera) faunasının incelenmesi. Türkiye Entomoloji Dergisi, 16 (3): 169-180.

Kılıç, A. Y., 1996a. Çamlıyayla (İçel) Tabanidae (Diptera) faunası üzerine araştırmalar. Türkiye Entomoloji Dergisi, 20 (2): 123-135.

Kılıç, A. Y., 1996b. Bilecik ili Tabanidae (Diptera) faunası üzerine araştırmalar. Anadolu Üniversitesi Fen Fakültesi Dergisi, 1: 45-57.

Kılıç, A. Y., 1996c. Türkiye Tabanidae (Diptera) faunası için iki yeni kayıt ve bazı türlerin yeni lokalite kayıtları. Anadolu Üniversitesi Fen Fakültesi Dergisi, 2: 105-115.

Kılıç, A. Y., 1999. Trakya Bölgesi Tabanidae (Diptera) faunası. Turkish Journal of Zoology, 23 (1): 67-89.

Kılıç, A. Y., 2001a. The Tabanidae (Diptera) Fauna of Balıkesir Province. Turkish Journal of Zoology, 25: 395-402.

Kılıç, A. Y., 2001b. The Tabanidae (Diptera) fauna of Çanakkale Province. Turkish Journal of Zoology, 25: 403-411.

Kılıç, A. Y., 2001c. The Tabanidae (Diptera) fauna of Kütahya Province of Turkey. Journal of Entomological Research Society. 3 (3): 29-41.

Kılıç, A. Y., 2003. Bursa ve Yalova illeri Tabanidae (Diptera) faunası üzerinde araştırmalar. Türkiye Entomoloji Dergisi, 27 (3): 207-221.

Kılıç, A. Y., 2004. Bolu İli Tabanidae (Diptera) faunası. Türkiye Entomoloji Dergisi, 28 (1): 57-68.

Kılıç, A. Y., 2006. New additions and errata to the checklist of Tabanidae (Insecta:Diptera) fauna of Turkey. Turkish Journal of Zoology, 30 (2): 335-343.

Kılıç, A. Y. \& W. Schacht, 1995. Eine neue Bremsenart aus der West-Türkei (Diptera: Tabanidae). Entomofauna, 16 (10): 245-252.

Kılıç, A. Y. \& R. Öztürk, 2002. Sultandağı çevresinin Tabanidae (Diptera) faunası üzerine çalışmalar. Anadolu Üniversitesi Bilim ve Teknoloji Dergisi, 3 (2): 307-316.

Kılıç, A., F. Altunsoy \& Y. Afacan, 2014. New records for Turkish Tabanidae (Insecta: Diptera) fauna. Türkiye Entomoloji Dergisi, 38 (3): 245-253.

Krčmar, S., 2005. Response of horse flies (Diptera, Tabanidae) to different olfactory attractants. Biologia, 60: 611613.

Krčmar, S., A. Mikuska \& E. Merdić, 2006. Response of Tabanidae (Diptera) to different natural attractants. Journal of Vector Ecology, 31: 262-265.

Krčmar, S., A. Mikuska \& V. Radolic, 2009. Comparison of sampling tabanids (Diptera: Tabanidae) by four different potential attractants. Journal of Vector Ecology, 34: 608-613.

Leclercq, M., 1966a. Revision systematique et biogeographique des Tabanidae (Diptera) Palearctiques, Tabaninae. Memphis Institute of Royal Science Natural Belgium, II (80): 1-236.

Leclercq, M., 1966b. Tabanidae (Diptera) de Turquie Diagnosis d'Atylotus hendrixi, Haematopota coolsi, Haematopota delozi n. spp. Bulletin des Recherches Agronomiques de Gembloux, 1 (3): 463-477.

Leclercq, M., 1967a. Tabanidae (Diptera) de Turquie. II. Diagnosis D' Hybomitra okayi, Atylotus hendrixi, et Haematopota hennauxi n. spp. Bulletin des Recherches Agronomiques de Gembloux, 2 (1): 106-127.

Leclercq, M., 1967b. Tabanidae (Diptera) de Turquie. III. Bulletin des Recherches Agronomiques de Gembloux, 2 (4): 707-710. 
Loew, H., 1856. Neue Beitrage zur Kenntnis der Dipteren, Fünfter Beitrag. Programm der Königlichen Realschule zu Meseritz, 1856, 1-56.

Mihok, S., D. A. Carlson \& P. N. Ndegwa, 2007. Tsetse and other biting fly responses to Nzi traps baited with octenol, phenols and acetone. Medical and Veterinary Entomology, 21: 70-84.

Olsufjev, N. G., 1977. The Fauna of USSR Diptera, VII, 2: Tabanidae (Faune de 1'URSS insectes Dipteres, VII, 2: Tabanidae). Institute of the Russian Academy of Sciences (Travaux de l'Institut zoologique de l'Academie des Sciences des l'URSS) Moscow, Leningrad, Russia, New Series No. 113, 2nd Edition, 436 pp.

Peus, F., 1980. Über Bremsen aus der westlichen Paläarktis 1. Tabaninae, außer Hybomitra und Actylotus (Diptera: Tabanidae). Deutsche Entomologische Zeitschrift, 27 (4-5): 221-249.

Rubio, M. P., 2002. Fauna Iberica, Volume 18, National Museum of Natural Sciences, Madrid, Spain, 309 pp.

Schacht, W., 1983. Eine neue Bremsenart aus der Türkei (Diptera: Tabanidae). Entomofauna, 4 (27): $483-492$.

Schacht, W., 1984. Beitrag zu einigen palearktischen bremsen Arten vornehmlich aus der Türkei (Diptera: Tabanidae). Entomofauna, 5 (35): 483-498.

Schacht, W., 1985. Kleiner beitrag zur bremsen fauna der Türkei (Diptera: Tabanidae). Entomofauna, 6 (28): 501508.

Schacht, W., 1987. Ein weiterer Beitrag bremsen fauna der Türkei (Diptera: Tabanidae). Entomofauna, 8 (33): $485-$ 496.

Steinmann, H. \& L. Zombory, 1985. An Atlas of Insect Morphology. Academia Kiado, Budapest, 215 pp.

Timmer, J., 1984. Two new horse flies from Turkey (Diptera: Tabanidae). Entomologische Berichten, 44: 74-79.

Walker, F., 1854. "Tabanidae, 450-458" In: List of the Specimens of Dipterous Insects in the Collection of the British Museum. (Ed. J. E. Gray) Part 5-7, Suppl. 1, Department of Zoology, British Museum (Natural History), London, UK, $774 \mathrm{pp}$.

Yücel, Ş., 1987. İç Anadolu Bölgesinde Bulunan Tabanidae (Diptera) Türleri Üzerinde Araştırmalar. Ankara Üniversitesi Sağlık Bilimleri Enstitüsü, (Basılmamış) Doktora Tezi, 121 pp. 